岡山医誌（1991）103，1147～1158

\title{
急性白血病並びに類縁疾患に扔ける 造血幹細胞動態に関寸る研究
}

\author{
第 1 編 \\ 急性白血病における Leukemic Blast Progenitors 由来コロニー形成能 \\ 並びに形成パターンの検討
}

岡山大学医学部第二内科学教室（指導：木村郁郎教授）

西 村 正 隆

(平成 3 年 8 月 8 日受稿)

Key words：急性白血病, 白血病由来幹細胞, 造血幹細胞

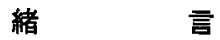

近年，急性非リンパ性白血病 (ANLL) 患者 の末梢血あるいは骨髄血より，白血病芽球より なるコロニーが形成されることが，諸家により 報告されている(1)23).コロニー形成細胞は, 光顕 的にも電顕的にももとの白血病細胞と同定さ れ(1)2)4, 染色体異常を伴う症例ではコロニ一構成 細胞にも同様の核型異常が認められる5こことから， これらの方法によって形成されたコロニーは白 血病細胞由来コロニーと考えられている.また, このコロニー形成細胞を新たにメチルセルロー ス培地で再培養すると二次性コロニ一が形成さ れるが6), 二次性コロニ一は一次性コロニーと形 態的に同様で，かつコロニー構成細胞も同様で あることから,この方法でとらえられる clonogenic cell は幹細胞としての性質を持つことが証明さ れた. 以来これら Leukemic blast progenitors 形成法を用い白血病病態の解析がなされるとと もに，in vitroに拈りる楽刜感受性の検討加ら 薬刜選択という点でその臨床応用が注目されて きた7)8. また近年，二次コロニー形成能あるい は液体培羕法によって得た Leukemic blast progenitors のコロニー形成能が白血病幹細胞の 自己再生能を表現することが明らかにされここ れらの方法を用い白血病幹細胞の自己再生能と 予後との関連が検討されている。しかし，これ
までにみられる多くの検討はコロニー形成，と くに一次コロニーの形成を day 7 あるいは day 10 と指定された時点で検討した，いわゆる数的 解析にとどまり，経時的観察すなわち形成パ夕 一ンという動的立場に立脚した解析はみられず， その検討は白血病病態をより動的立場から解析 する上に重要な情報を提供するものと考えられ る.今回著者は以上の観点に立ち, 定型的 ANLL において Leukemic blast progenitors 由来コ ロニ一形成を経時的に観察し，その形成能並び に形成パターンと病型, 病態並びに治療効果と の関連を検討することによって，白血病病態の 解析と治療効果の予知に対する一助とせんとし た。

\section{研究対象並びに方法}

1. 研究対象

1985年より1987年までに同山大学医学部第 2 内科において経験した定型的 ANLL 34例 [年 齢構成：16歳～86歳 (中央值48歳) 男女比：19： 15]，低形成型白血病 6 例 [年齢構成：67歳 77 葴（中央值74歳）男女比 $3: 3$ ] 対象とした。 2 . 研究方法

Leukemic blast progenitors 由来一次コロニ 一形成は Minden らのの方法に準じ行った。す なわち患者骨髄血または末梢血をへパリン加で 採取し, Ficoll-Hypaque 上に重層し，単核球層 
を分離したのち， Tリンパ球除去のために羊赤

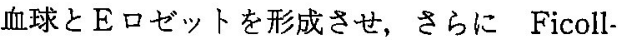
Hypaque 上に重層し, 単核球層を分離した。そ の後これによって得た単核細胞を軟寒天培地 $(0.3$ $\%$, enriched McCoy $5 \mathrm{~A}+20 \% \mathrm{FCS}+10 \% \mathrm{PHA}$ $-\mathrm{LCM}$, 細胞密度 $\left.2 \times 10^{5} / \mathrm{ml}\right)$ で $37^{\circ} \mathrm{C}, 5 \% \mathrm{CO}_{2}$ の条件下で培養した. Leukemic blast progenitors 由来コロニーは定型的 ANLL においては day 3，5，7，10，14 と経時的に観察し，コ口 ニー形成パターンを作成した後「day 7 でのコロ 二一数」,「コロニ一数最高值」「最高值までの 日数」「最高值からの $50 \%$ 減少日数」を算出し (図 1),これら各パラメーターと病態並びに治 療効果との関連について検討した。一部の定型 的 ANLLにおいては寛解導入療法後の骨䯣内 白血病細胞減少曲線 ${ }^{10)}$ を作成し，その曲線より得 られる各パラメーター（図2）と，上記のコロ ニー形成パターンより得られた各パラメーター との関連について検討を行った。また低形成型

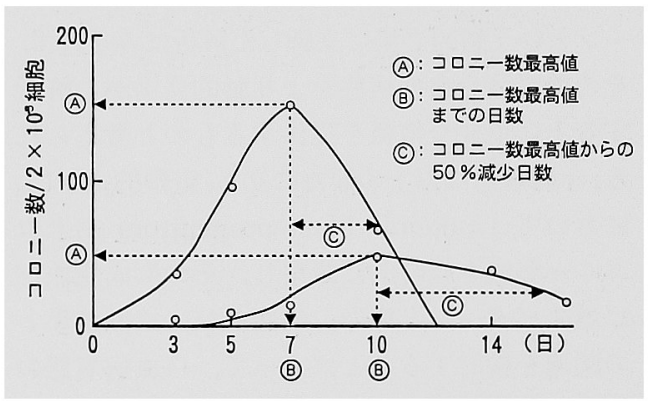

図 1 Leukemic Blast Progenitors 由来コロニー 形成パターン

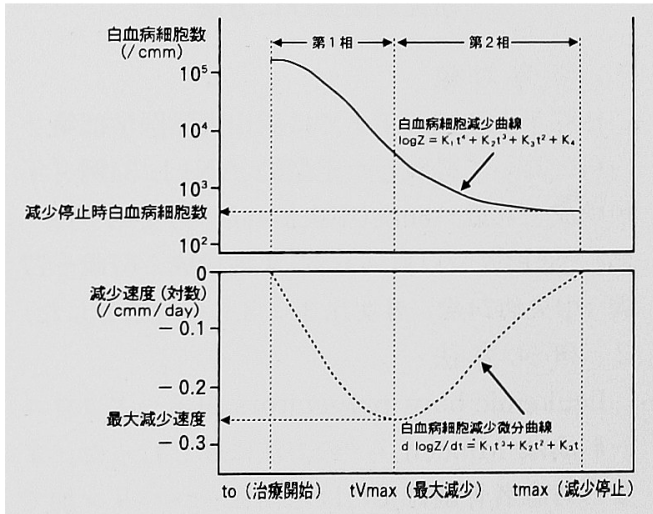

目 2 骨䯣内白血病細胞減少曲線
白血病症例においては day10におけるコロニー 形成能を検討し，定型的 ANLL と比較検討し た.なおコロニーは構成細胞数20個以上の細胞 集団をもってした（図 3，4）。なお有意差検定 には“Student's” t-testを用いた。

\section{成綪}

1. 骨㕼血と末梢血由来コロニー形成能の比較 検討

未治療同一症例における骨䯣血並びに末梢血 による一次コロニー数（最高值）は表 1 , 国 5 に示す如くで，骨髄血を用いた場合のコロニー 数は $160 \pm 228$ ，末梢血では $174 \pm 144$ と有意差は 認められなかったが、各症例ごとのコロニ一数 の検討では末梢血由来コロニー数の多い症例が 多く認められ，また骨䯣血由来コロニー数/末梢

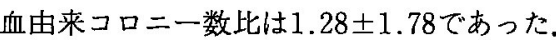

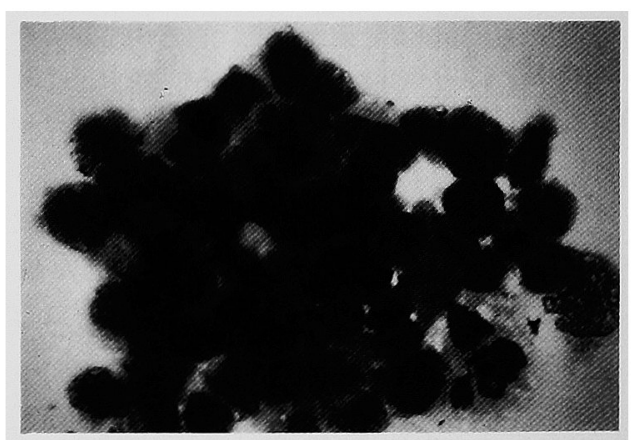

区 3 Leukemic Blast Progenitors 由来コロニー (M 2)

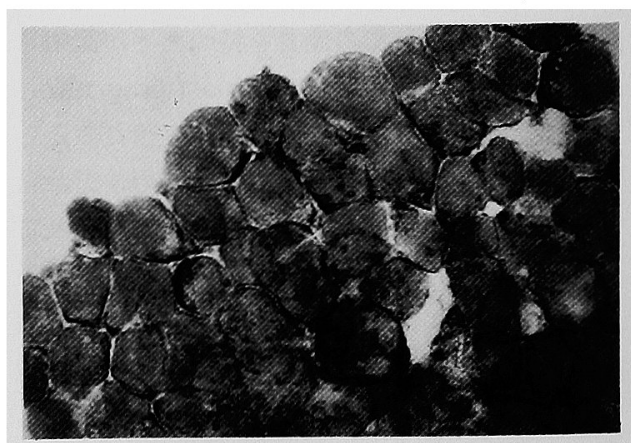

区 4 Leukemic Blast Progenitors 由来コロニー (M 3 ) 
表 1 骨䯙血並びに末梢血による Leukemic Blast Progenitors 由来コロニー形成能の比較

\begin{tabular}{|c|c|c|c|}
\hline & $\begin{array}{c}\text { 骨䯙血由来 } \\
\text { コロニ一数 } \\
\text { (最高値) } / 2 \\
\times 10^{5} \text { 細胞 }\end{array}$ & $\begin{array}{c}\text { 末梢血由来 } \\
\text { コロ二-数 } \\
(\text { 最高値) } / 2 \\
\times 10^{5} \text { 細胞 }\end{array}$ & $\begin{array}{l}\text { 骨蹎血由来 } \\
\text { コロニー数/ } \\
\text { 末梢血由来 } \\
\text { コロニ一数比 }\end{array}$ \\
\hline 症例 1 & 39 & 456 & 0.09 \\
\hline 症例 2 & 97 & 182 & 0.53 \\
\hline 症例 3 & 435 & 189 & 2.30 \\
\hline 症例 4 & 0 & 164 & 0 \\
\hline 症例 5 & 70 & 98 & 0.71 \\
\hline 症例 6 & 32 & 115 & 0.28 \\
\hline 症例 7 & 2 & 57 & 0.04 \\
\hline 症例 8 & 291 & 72 & 4.04 \\
\hline 症例 9 & 25 & 60 & 0.42 \\
\hline 症例10 & 104 & 124 & 0.84 \\
\hline 症例11 & 837 & 136 & 6.15 \\
\hline 症例12 & 67 & 537 & 0.12 \\
\hline 症例 13 & 92 & 84 & 1.10 \\
\hline 平均值 & $160 \pm 228$ & $174 \pm 144$ & $1.28 \pm 1.78$ \\
\hline
\end{tabular}

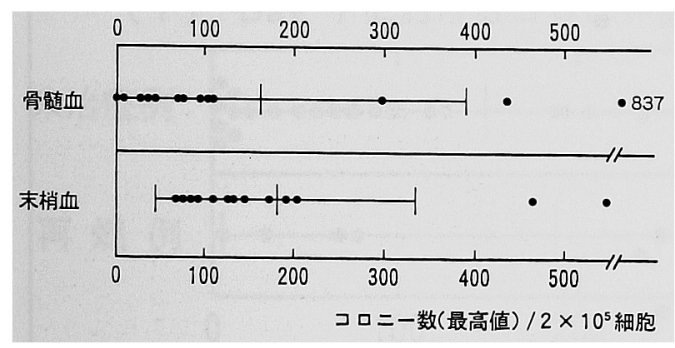

図 5 骨骾血並びに末梢血による Leukemic Blast Progenitors 由来コロニー形成能の比較

2.コロニ-ー形成能と病型との関連

定型的 ANLLにおける「コロニ一数最高値」 を $\mathrm{FAB}$ 分類別に比較したが，その結果は図 6 に示す如くで，M 2，M 5 で比較的多くのコ口 ニ一形成能を認めた。 また低形成型白血病にお けるコロニー最高值（骨髄血）は図 7 に示す如 くで定型的 ANLL では148土205であったのに 比し，低形成型白血病では $22 \pm 25$ と有意にコロ 二一形成能の低下が認められた。

3.コロニー形成能並びにコロニー形成パター ンと末梢白血病細胞数, 骨䯣内白血病細胞 数との関連

Leukemic blast progenitors 由来コロニー形 成能並びに形成パターンから得られた各パラメ 一ターと末梢白血病細胞数, 骨䯣内白血病細胞

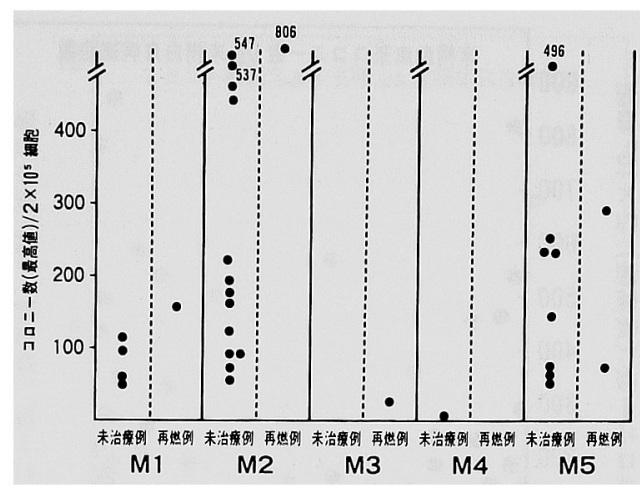

図6 Leukemic Blast Progenitors 由来コロニー の検討

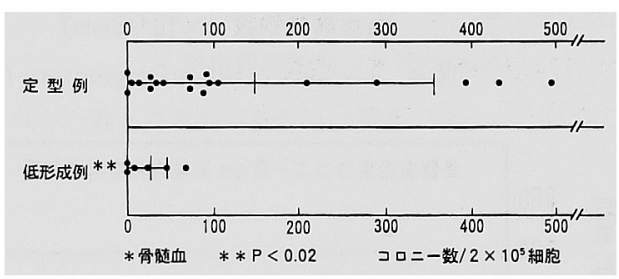

図 7 定型的白血病並びに低形成型白血病における Leukemic Blast Progenitors 由来コロニー 数*の検討

数との関連について検討した.その結果は図 8， 9，10に示す如くで，まず「末梢血由来コロニ 一数最高値」と「末梢白血病細胞数」「骨䯣内 白血病細胞数」との間には相関は認められなか った（図 8)。つぎに「骨髄血由来コロニー数最 高值」と「末梢血白血病細胞数」,「骨剈道内白血 病細胞数」との関連について検討したが，その 結果は図 9 に示す如くで，両者間に相関関係は

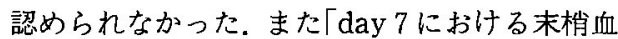
由来コロニ一数」と「末梢血白血病細胞数」,「末 梢血由来コロニ一数最高值からの $50 \%$ 減少日数」 と「末梢白血病細胞数」との関連について检討 したが，両者とも有意の相関は認められなかっ た（図10）。

4.未治療時並びに再燃時におけるコロニ一形 成能，コロニー形成パターンの検討

定型的 ANLLにおけるLeukemic blast progenitors 由来コロニー形成能並びに形成パター ンを未治療例，再燃例において検討した．その

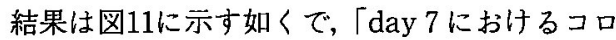




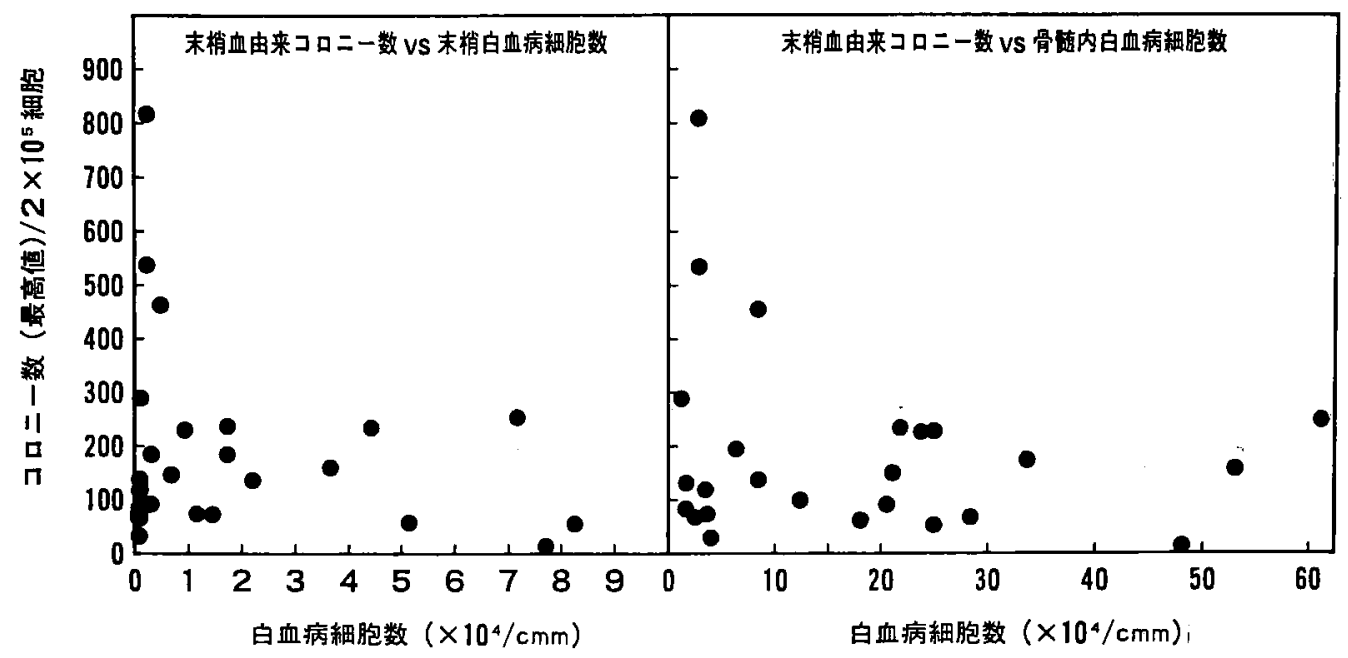

図 8 Leukemic Blast Progenitors 由来コロニー数と白血病細胞数との関連 (1)

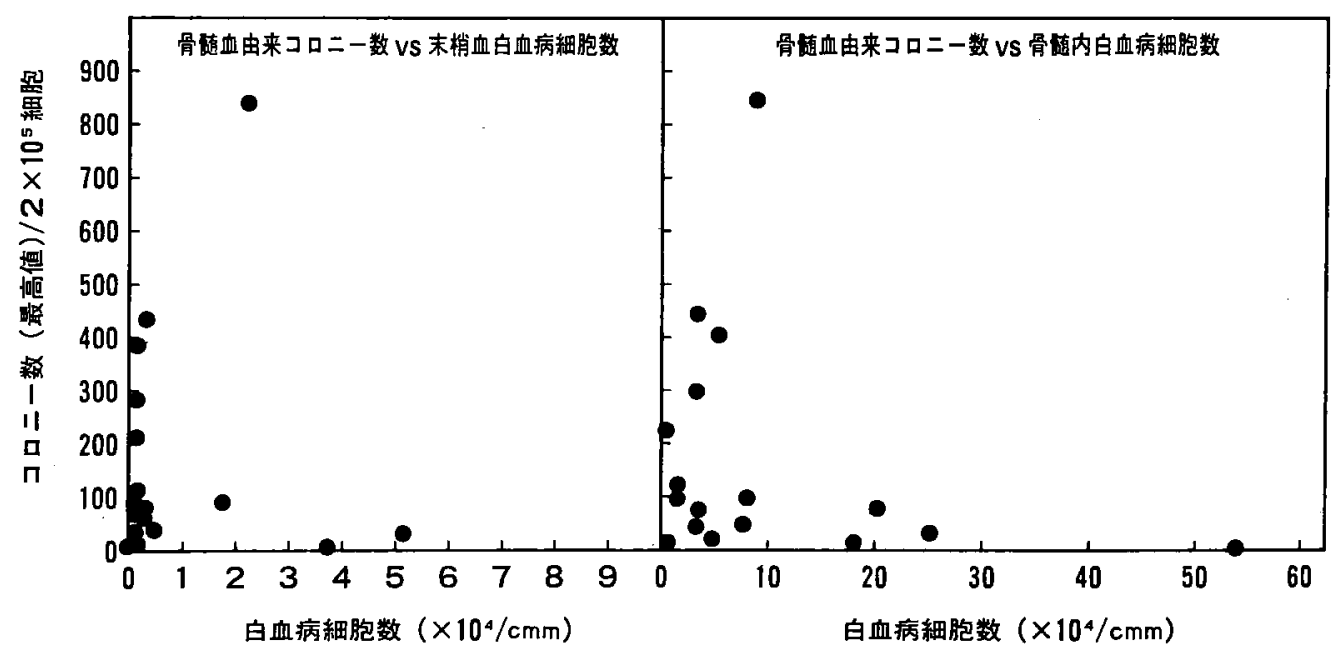

図 9 Leukemic Blast Progenitors 由来コロニー数と白血病細胞数との関連 (2)

ニ一数」,「コロニー数最高值」の比較では両者 間に有意差は認められなかった。また形成パ夕 ーンから得た各パラメーターについて未治療例, 再燃例間で比較検討したが，その結果は図12に 示す如くで，「最高値までの日数」は各々 $9.3 \pm$ 3.6 日, $9.0 \pm 2.0$ 日と両者間で差を認めなかった が,「コロニ一数最高值からの $50 \%$ 減少日数」は 各々 $3.3 \pm 1.5$ 日，6.5 2.3 日と再燃例で有意の 延長が認められた。
5.コロニー形成能並びにコロニー形成パター ンと化学療法効果との関連

化学療法効果とコロニー形成パターンとの関 連について検討したが，その結果は図13，14に

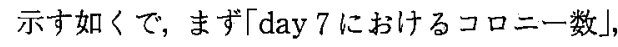

「コロニー数最高値」を寞解例、非寛解例で比 較すると，䆓解例における「day 7 におけるコ口 二一数」は198 187 ,「コロニ一数最高值」は $233 \pm$ 188 ，一方非寛解例では69 解例で有意に低いコロニー形成能が示された。 また「コロニ一数最高值までの日数」,「コロニ 

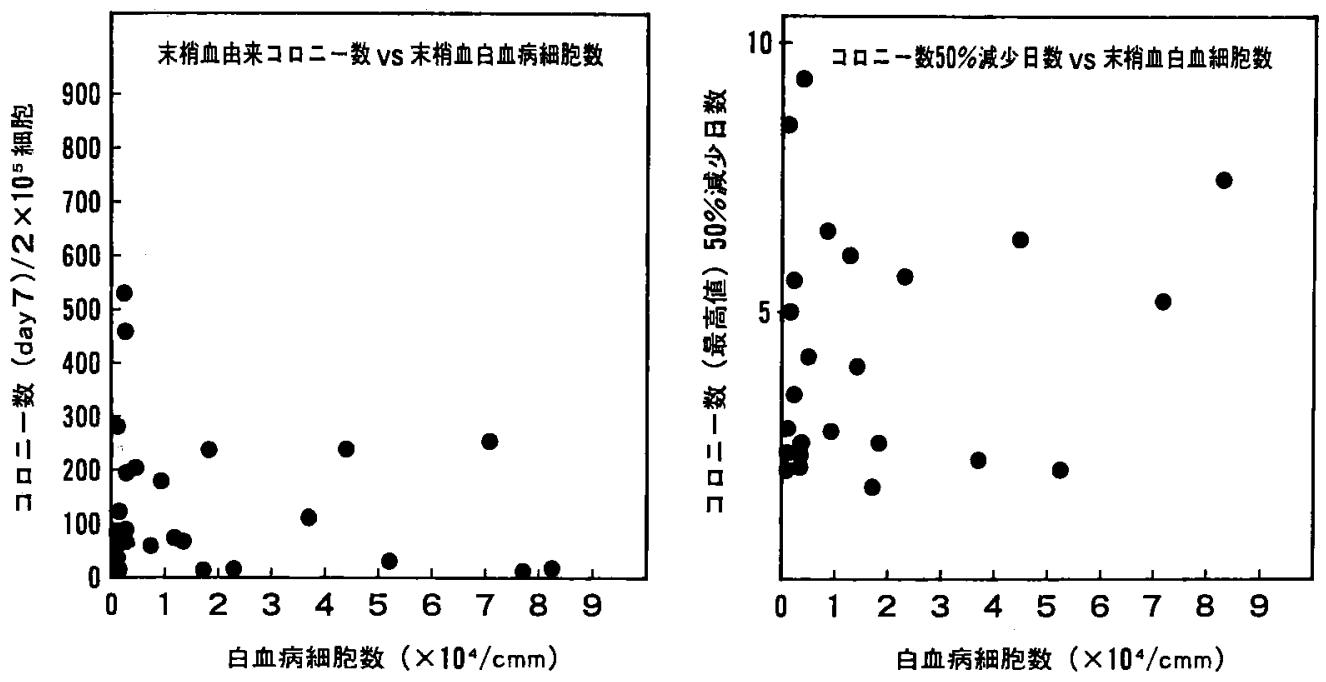

図10 Leukemic Blast Progenitors 由来コロニー数と白血病細胞数との関連 (3)

\section{（） Day 7におけるコロニー数}

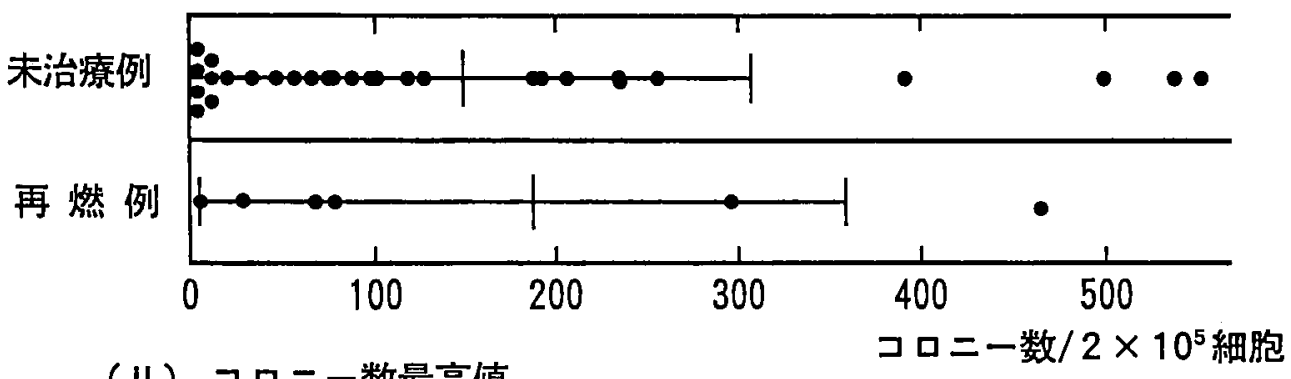

（II）コロニー数最高値

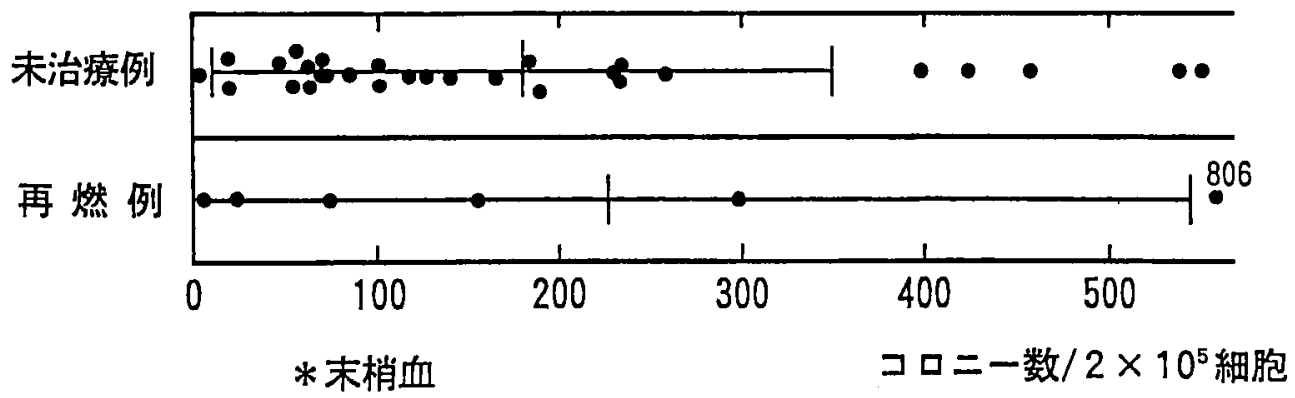

図11 未治療例，再燃例における Leukemic Blast Progenitors 由来コロニ一形成能*の比較検討

一数最高值からの $50 \%$ 減少日数」と化学療法効 果との関連について検討したが，その結果は困 14に示す如くで，寛解例，非寛解例における「最 高値までの日数」は各々 $9.0 \pm 3.0$ 日， $10.1 \pm 4.0$ 日と差は認めなかったが,「最高值からの50\%減

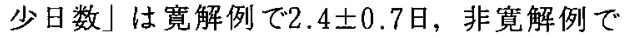
$4.2 \pm 1.6$ 日と非寛解例で有意の延長が認められ た. 


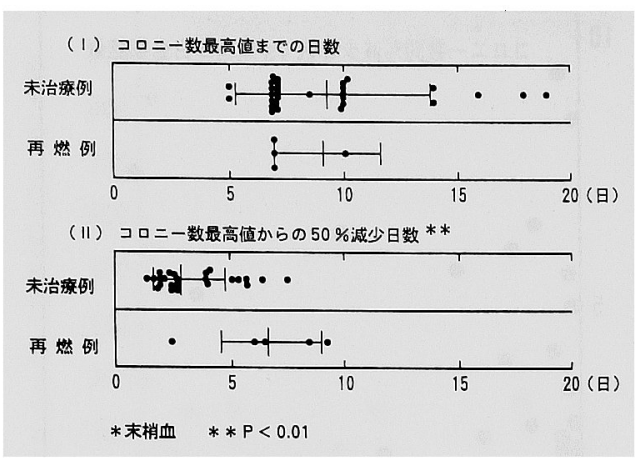

目12 未治療例, 再燃例に扔了 Leukemic Blast Progenitors 由来コロニー形成パターン*の比 較検討
6. 骨䯣内白血病細胞減少動態とLeukemic blast progenitors 由来コロニー形成パター ンとの関連

寬解導入療法後の骨䯣内白血病細胞減少曲線 における各パラメーターとコロニー形成パター ンとの関連を検討したが，その結果図15に示す 如く，「コロニ一数最高值からの $50 \%$ 減少日数」 と骨䯣内白血病細胞減少曲線に扔ける「第二相 平均減少加速度」との間に末梢血由来コロニー では $\mathrm{r}=0.723(\mathrm{p}<0.05)$, 骨䯣血由来コロニ 一では $\mathrm{r}=0.637(\mathrm{p}<0.05)$ の正の相関が認め られた。

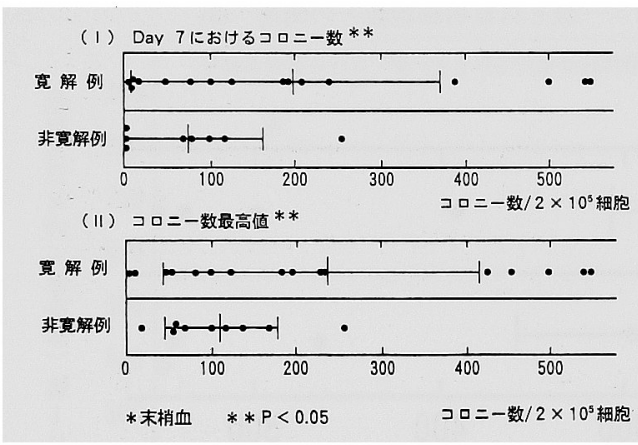

図13 Leukemic Blast Progenitors 由来コロニー 形成能*と化学療法効果
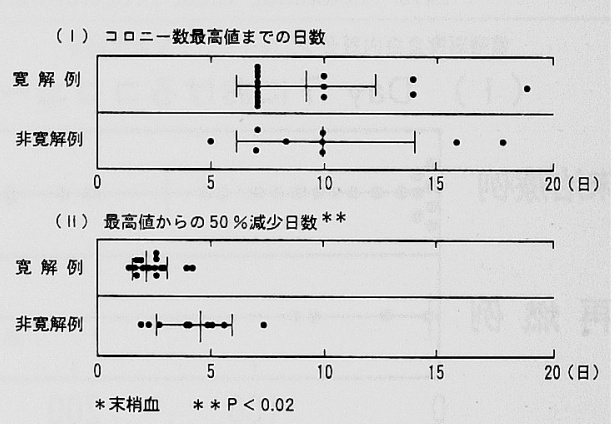

困14 Leukemic Blast Progenitors 由来コロニー 形成パターン*と化学療法効果

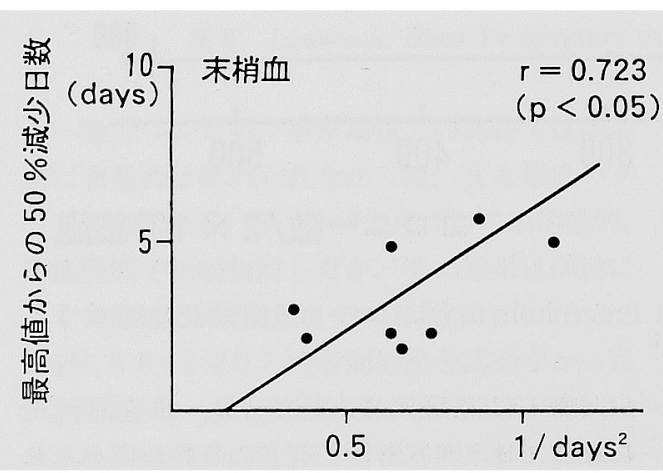

第 2 相平均減少加速度

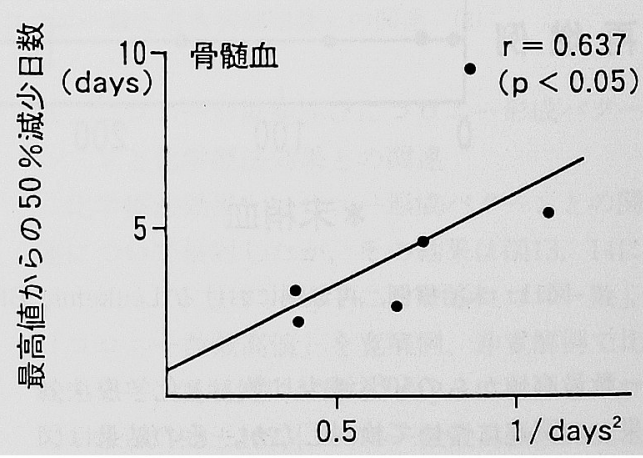

第 2 相平均減少加速度

図15 骨髄内白血病細胞減少動態と Leukemic Blast Progenitors 由来コロニー形パターン 


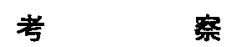

Leukemic blast progenitors 由来コロニー形 成法の臨床応用が，コロニー，クラスターの形 成能と予後との関連78), 抗白血病剂の添加によ

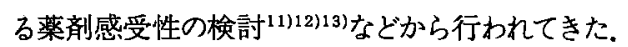
1974年 Moore ら ${ }^{7}$ は急性骨䯣性白血病 (AML) 患者の骨䯣または末梢血液細胞を二重軟寒天法 で培養し，クラスター，コロニー形成能からこ れら症例を(1)コロニー形成群（構成細胞数 40 個 以上)(2)大クラスター形成群(構成細胞数 3 40 個) (3)小クラスター形成群（構成細胞数 3 20 個）(4)無形成群の 4 群に分類した結果, 賁解導 入率は(3)群が最も高く, (2)群, (4)群で低率であ ったとしている.しかしこの方法でのコロニー 形成率は低く，しかも白血病クローン由来のも ののみを選択的に培荃できないという問題点が あった. その後, Leukemic blast progenitors 由来コロニーをより選択的に培養する方法が諸 家により試みられてきたが,その多くはPHAを stimulatorとして使用している.その後 Minden ら”はT細胞を除去した AML 患者末梢血の白 血病細胞をPHA-LCM(ヒト末梢白血球をPHA で刺激し，培盖した上清）添加メチルセルロー ス培地で培養し, 一次コロニー, 二次コロニー の形成について検討し，二次コロニーの形成能 を plating efficiency 2 (PE 2) として表現し た.このPE 2 は白血病細胞の自己再生能を反映 し, 患者の予後と相関しているとされている(6)14)15). すなわち, PE 2 の低い症例は高い症例に比し, 化学療法によって寛解に導入されやすく，かつ 生存期間も長く, PE 2 の高い症例, すなわち自 己再生能の高い Leukemic blast progenitors を 有する白血病患者では，白血病細胞がたえず活 発に增殖するため難治性であると考えられてい る.最近奈良ら ${ }^{16)}$ はLeukemic blast progenitors の液体培養法を開発しているが,これは白血病 患者末梢血より単核球層を分離し，さらに $\mathrm{T}$ 細 胞を除去したのち PHA-LCM または conditioned medium さらに FCS を加えた液体培地 中で 1 週間培養, その後細胞を回収しこれを PHA-LCM または conditioned medium さら に FCS を加えメチルセルロース培地にてコロ
ニ一形成を行うものである。これによって得ら れる Leukemic blast progenitors は幼若細胞 からのrecruitment ではなく自己再生によって増 殖することが生物学的に証明されており ${ }^{16)}$ ここの 液体培養法は Leukemic blast progenitors $の$ 自己再生能を反映する培養法と考えられている.

さて著者は Minden らの方法に準じ Leukemic blast progenitors 由来一次コロニー形成を経時 的に観察し，主にその形成パターンから得られ た各パラメーターと病態, さらに化学療法効果 との関連について検討したわけであるが，まず 骨䯣血あるいは末梢血を用いたコロニー形成率 は両者で特に差は認められず,「コロニー数最高 值」を各病型でみると M 2, M 5 で比較的多く のコロニー形成が認められた，また低形成型白 血病症例における Leukemic blast progenitors 由来コロニー形成能を定型的 ANLL 症例と比 較検討した結果, 低形成型白血病症例ではコロ 二一形成能が低かった，低形成型白血病は骨䯣 低形成を主徵とし, 沉血球減少, 芽球の低率な 出現を血液学的特徴としており，臨床的にはく すぶり型白血病の性格を示す点などその病態特 異性が注目されている.高橋ら五は本症における 病像形成因子の一つとして,まず宿主側要因と して加令, 免疫能が, そして細胞側要因とし白 血病細胞の增殖動㮩が相互に関与するとし, 白 血病細胞の小型化また labeling index の低值で あることを明らかにしているが，今回得た結果 はこれら低形成型白血病の臨床血液学的特異性 の背景とし, 白血病幹細胞動態が関与する可能 性を示すものと考之られた。つぎに形成パター ンから得られた各パラメーターと末梢血白血病 細胞数, 骨㖪内白血病細胞数について検討した が,「末梢血由来コロニー数最高値」と「末梢血 白血病細胞数」,「骨髄内白血病細胞数」との間 に相関を認めず,「骨鹃血由来コロニ一数最高值」 と「末梢血白血病細胞数」,「骨㵦内白血病細胞 数」との間にも相関を認めなかった。また「day 7 におけるコロニ一数」あるいは「コロニ一数 最高值からの $50 \%$ 減少日数」と「末梢血白血病 細胞数」との間にも相関を認めなかった.つぎ に未治療例, 再燃例について検討したが,「day 7 に扔けるコロニ一数」,「コロニー数最高値」, 
「最高值までの日数」は未治潦例, 再燃例間に 差が認められなかったが,「コロニー数最高值か らの $50 \%$ 減少日数」は未治療例 $3.3 \pm 1.5$ 日, 再 燃例 $6.5 \pm 2.3$ 日と後者で有意に延長していた.

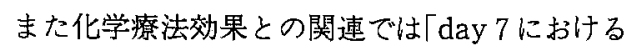
コロニー数」,「コロニ一数最高值」ともに寛解 例で高く，一次コロニー形成によって表現され る分化增殖能の高いLeukemic blast progenitors は抗白血病剤に対する感受性が高いと考え られた.すでに周知の如く正常造血幹細胞は， 盛んな分化增殖を伴っており ${ }^{18)}$, そのことが化学 療法後の骨䯣低形成いわゆる血液毒性の発現に 関係すると考えられるが, 高い分化増殖能と化 学療法への感受性は Leukemic blast progenitorsについても存在するものと言えよう。また 非寛解例では「最高値加の $50 \%$ 減少日数」が 有意に延長していた点が注目された. すでにコ ロニ一形成能と化学療法効果について McCulloch $ら^{15}$ は二次コロニ一形成能が化学潦法効果 と関係するとしている，今回 Leukemic blast progenitors 由来一次コロニー形成を経時的に観 察した著者の成績から，「コロニー数最高値」が 高くかつ「最高値からのコロニ一数減少速度」 が速い群と,「コロニー数最高値」が低く,「最 高值からのコロニ一数減少速度」の遅い群が存 在し, 前者では寛解例が, 後者では非寛解例が 多く, 一次「コロニ一数最高值」,「コロニ一数 最高値からの50\%減少日数」は化学療法に対す る反応性を予知する有用なパラメーターと考之 られた。

今回設定された「コロニ一数最高值からの 50 \%減少日数」について一ケの Leukemic blast progenitor を考之た場合，その Leukemic blast progenitor が一定回数の分裂を終われば，その まま死滅するようなもの，すなわち自己再生能 が低ければ, そのLeukemic blast progenitor か らのコロニーは早く死滅し,一方 Leukemic blast progenitor が一定回数の分裂が終方っても，引 き続き增殖できるようなもの，すなわち自己再 生能が高ければれその Leukemic blast progenitor からのコロニーは長く存在すると考之られる が, コロニーの経時的な観察という面から見れ ば, 自己再生能の高いコロニーが多ければ，コ
ロニ一数最高值からのコロニ一数の減少は遅く なると考えられる。すすなわち，コロニー数「最 高值からの50\%減少日数」は Leukemic blast progenitors の自己再生能をある程度反映してい るものと言えよう。また教室では ANLLにお いて寛解導入療法後の骨髄内白血病細胞減少曲 線を作成し, 減少曲線における第二相（最大減 少から減少停止にいたる期間) の平均減少加速 度を寛解例，非寛解例別に検討したところ，非 寞解例ではこの第二相平均減少加速度が大きい ことを明らかにしている(10).この第二相平均減少 加速度は白血病細胞減少速度に対し反対の方向 に働き，従って白血病細胞減少に对する制止力 と考えられ，この制止力は低細胞回転群あるい は薬剤耐性細胞群に起因するものではないかと 考之られているが，今回骨髓内白血病細胞減少 曲線とコロニー形成パターンから得られた各パ ラメーターとの関連について検討したところ「骨 䯣内白血病細胞減少曲線の第二相平均減少加速 度」と Leukemic blast progenitors 由来「コ ロニー数最高値からの $50 \%$ 減少日数」との間に 正の相関関係が認められた．このことは非寛解 例における白血病細胞の減少を抑制する細胞群 は自己再生能の高い細胞群によって構成される ことを示唆するとともに, これらの細胞群が抗 白血病剂に対する抵抗性の大きな背景因子とな つているものと考えられる。すでに抗白血病剂 はPE 2 に封する影響から (1) cytosinearabinoside (ara-C)のようにその形成を抑制す る薬剤(2)adriamycinのように抑制効果がほとん どない菜戍(3)5-azacytidineのように促進させる 薬剂にわけられているが(1920)，今後コロニ一形成 パターンの解析から「50\%減少日数」が長い症 例に対しては寛解導入あるいは筧解後の化学療 法に際し， ara-Cの上うな自己再生能を抑制す る薬剤を選択する必要があるものと考之られる. またLeukemic blast progenitors $の$ 自己再生能 のメカニズムを今後解明することが必要と考之 られるが, 最近分子生物学の進歩により遺伝子 組み替えによる各種造血因子が作成されている. このうち組み替之型 IL- ${ }^{211}$, GM-CSF ${ }^{22) 23), ~}$ G-CSF ${ }^{24) 25)} は$ Leukemic blast progenitors $の$ 自己再生能及び分化增殖能を促進するとされて 
いる.また GM-CSF ${ }^{26)}, \mathrm{M}-\mathrm{CSF}^{27}$ 遺伝子は染色 体 $5 \mathrm{q}$ に座位があり, M-CSF 受容体は癌遺伝子 fms の座物であり ${ }^{28)}$, fms 遺伝子も $5 \mathrm{q}$ に座位 があることが明らかにされている，すでに白血 病や骨髄異形成症候群の一部に $5 \mathrm{q}^{-}$の症例が報 告されており 29),このような症例では CSF の産 生異常また CSF 受容体の異常が推定されてい る.また Young ら ${ }^{30 / 311} は$ 白血病細胞に GM-CSF 遗伝子が発現され，GM-CSFの分泌されている 症例を報告しているが，この様な症例において は白血病細胞の autocrine growth による増殖 を示唆するものと考之られる。この様に Leukemic blast progenitors の增殖に関してはいくつかの メカニズムが推定されているが，いまだに単一 メカニズムによって説明することは困難であり， Leukemic blast progenitors $の$ 自己再生能の カニズムを解明し，白血病治療に応用すること が今後必要と考えられる。

\section{結論}

急性非リンパ性白血病 (ANLL) において Leukemic blast progenitors 由来コロニー形成 を経時的に観察し，その形成能並びに形成パタ ーンと病型, 病態, 治療効果との関連について 検討を行った。その結果，

1，骨髄血あるいは末梢血を用いたコロニー 形成能は両者間で差が認められなかった。

2. 病型別コロニー形成能の検討では M 2 , M 5 で比較的多くのコロニ一形成が認められた。

3. 低形成型白血病症例においては, 定型的 ANLLに比しコロニー形成能の低下が認められ た.

4.「末梢血/骨䯣血由来コロニ一数最高値」 と「末梢血白血病細胞数」,「骨髄内白血病細胞 数」の間に相関は認められなかった。「day 7 に おけるコロニー数」あるいは:「コロニー数最高
值からの $50 \%$ 減少日数」と「末梢血白血病細胞 数」との間にも相関が認められなかった。

5. 未治療, 再燃症例問でコロニー形成パ夕 ーンを検討した結果, 特に「コロニー数最高值 からの50\%減少日数」が未治療例では $3.3 \pm 1.5$ 日, 再燃例では6.5 2 2.3日と後者で有意の $(\mathrm{p}<$ 0.01）延長が認められた。

6. 化学療法効果とコロニー形成パターンと の関連を検討した結果「day 7 におけるコロニー 数」,「コロニ一数最高值」では寛解例で198 187 , $233 \pm 183$ ，一方非寞解例では69 $\pm 77 ， 107 \pm 66$ と 後者で有意に $(p<0.05)$ 低いコロニー形成能 が示された.「コロニ一数最高値からの50\%減少 日数」は寛解例で $2.4 \pm 0.7$ 日, 非寛解例で $4.2 \pm$ 1.6 日 後者で有意の $(\mathrm{p}<0.02)$ 延長が認めら れた。

7.コロニー形成パターンと骨髄内白血病細 胞減少動態との関連を検討した結果,「コロニー 数最高值からの $50 \%$ 減少日数」と「骨随内白血 病細胞減少曲線の第二相平均減少加速度」との 間に末梢血由来コロニーでは $\mathrm{r}=0.723(\mathrm{p}<$ $0.05)$, 骨髄血由来コロニーでは $\mathrm{r}=0.637(\mathrm{p}<$ 0.05)の正の相関関係が認められた.

以上の結果を得たが, Leukemic blast progenitors 由来コロニー形成能とくに形成パターンの 解析は白血病病態の解析のみならず，化学療法 効果の予知において重要な情報を提供するもの と考之られ，特に化学療法効果の発現には Leukemic blast progenitors $の$ 自己再生能が大きな 要素となっていると考えられた。

稿を終えるにあたり御指導, 御校閲を睗わった木 村郁郎教授並びに高橋功講師, 中央检查部真田浩助 教授に深䓕なる謝意を表します。

本論文の要旨は第30回日本臨床血液学会総会 (岡 山）に扮いて発表した。

\section{文献}

1) Buick RN, Till JE, McCulloch EA : Colony assay for proliferative blast cells circulating in myeloblastic leukemia. Lancet (1977) 16, 862-863.

2) Minden MD, Till JE, McCulloch EA : Proliferative state of blast cell progenitors in acute myeloblastic leukemia (AML). Blood (1978) 52, 592-599. 
3) Park $\mathrm{CH}$, Savin MA, Hoogstraten B, Amare M and Hathaway P : Improved growth of in vitro colonies in human acute leukemia with the feeding culture method. Cancer Res (1977) 37, 45954601.

4) McCulloch EA, Howatson AF; Buick RN, Minden MD and Izaguirre CA : Acute myeloblastic leukemia considered as a clonal hemopathy. Blood Cells (1979) 5, 261-282.

5 ) Moore MAS, Metcalf D : Cytogenetic analysis of human acute and chronic myeloid leukemic cells cloned in agar culture. Int J Cancer (1973) 11, 143-152.

6) Buick RN, Minden MD, McCulloch EA : Self-renewal in culture of proliferative blast progenitor cells in acute myeloblastic leukemia. Blood (1979) 54, 95-104.

7) Moore MAS, Spitzer G, Williams N, Metcalf D, Buckley J : Agar culture studies in 127 cases of untreatad acute lecukemia (the prognostic value of reclassification of leukemia according to in vitro growth characteristics). Blood (1974) 44, 1-18.

8) Browman G, Goldberg J, Gottlieb AJ, Preisler HD, Azarnia N, Priore RL, Brennan JK, Vogler WR, Winton EF, Miller KB and Grunwald $\mathrm{H}$ : The clonogenic assay as a reproducible in vitro system to study predictive parameters of treatment outcome in acute nonlymphoblastic leukemia. Am J Hemat (1983) 15, 227-235.

9) Minden MD, Buick RN, McCulloch EA : Seperation of blast cell and T-lymphocyte progenitors in the blood of patients with acute myeloblastic leukemia. Blood (1979) 54, 186-195.

10）大本英次郎，高橋 功，依光聖一，原 雅道，稲坦登稔，仲田浩之，青山重男，木村郁郎，喜多嶋康一，真 田 浩：急性白血病初回寛解導入に扝计る骨髄内白血病細胞減少動態の解析. 臨血 (1986) 27, 1590-1595.

11) Preisler HD : Prediction of response to chemotherapy in acute myelocytic leukemia. Blood (1980) 56, 361-367.

12) Park CH, Wiernik PH, Morrison FS, Amare M, Sloten KV and Maloney TR : Clinical correlation of leukemia clonogenic cell chemosensitivity assessed by in vitro continuous exposure to drugs. Cancer Res (1983) 43, 2346-2349.

13) Marie JP, Zittoun $\mathrm{R}$, Thevenin $\mathrm{D}$, Mathieu $\mathrm{M}$ and Viguie $\mathrm{F}$ : In vitro culture of clonogenic leukaemic cells in acute myeloid leukaemia : growth pattern and drug sensitivity. Br $\mathbf{J}$ Haematol (1983) 55, 427-437.

14) McCulloch EA, Buick RN, Curtis JE, Messner HA and Senn JS: The heritable nature of clonal characteristics in acute myeloblastic leukemia. Blood (1981) 58, 105-109.

15) McCulloch EA : Experimental approaches to outcome prediction in acute myeloblastic leukemia. Recent Results Cancer Res (1984) 94, 76-92.

16) Nara N, McCulloch EA : The proliferation in suspension of the progenitors of the myeloblastic leukemia. Blood (1985) 65, 1484-1493.

17）高橋 功, 厚井文一：非定型的白血病（概念とその臨床像の特異性）. 臨血（1981）22，757-765.

18）小川眞紀雄，池淵研二：コロニ一形成法を用いた造血幹細胞の增殖と分化に関する研究。実験医学 (1986) 4, $874-877$.

19) Buick RN, Chang LJ-A, Messner HA, Curtis JE and McCulloch EA : Self-renewal capacity of leukemic blast progenitor cells. Cancer Res (1981) 41, 4849-4852.

20) Motoji $T$, Hoang $T$, Tritchler $D$ and McCulloch EA : The effect of 5-azacytidine and its analogues on blast cell renewal in acute myeloblastic leukemia. Blood (1985) 65, 894-901.

21) Miyauchi J, Kelleher CA, Yang Y-C, Wong GG, Clark SC, Minden MD, Minkin S and McCulloch EA : The effects of three recombinant growth factors, IL-3, GM-CSF and G-CSF, on the blast cells 
of acute myeloblastic leukemia maintained in short-term suspension culture. Blood (1987) 70, 657 -663 .

22) Hoang $T$, Nara N, Wong G, Clerk S, Minden MD, McCulloch EA : Effects of recombinant GM-CSF on the blast cells of acute myeloblastic leukemia. Blood (1986) 68, 313-316.

23) Griffin JD, Herrmann DYF, Wagner DWK, Sabbath KD : Effects of recombinant human GM-CSF on proliferation of clonogenic cells in acute myeloblastic leukemia. Blood (1986) 67, 1448-1453.

24) Nara N, Murohashi I, Suzuki T, Yamashita Y, Maruyama Y, Aoki N, Tanikawa S and Onozawa $\mathrm{Y}$ : Effects of recombinant human granulocyte colony-stimulating factor (GM-CSF) on blast progenitors from acute myeloblastic leukaemia patients. Br J Cancer (1987) 56, 49-51.

25) Kelleher C, Miyauchi J, Wong G, Clerk S, Minden MD and McCulloch EA : Synergism between recombinant growth factors, GM-CSF and G-CSF, acting on the blast cells of acute myeloblastic leukemia. Blood (1987) 69, 1498-1503.

26) Le Beau MM, Westbrook CA, Diaz MO, Larson RA, Rowlex JD, Gasson JC, Golde DW and Sherr CJ : Evidence for the involvement of GM-CSF in the deletion $(5 \mathrm{q})$ in myeloid disorders. Science (1986) 231, 984.

27) Pettenati MJ, Le Beau MM, Lemons RS, Shima EA, Kawasaki ES, Larson RA, Sherr CJ, Diaz MO and Rowley JD : Assignment of CSF-1 to $5 \mathrm{q} 33.1$ (evidence for clustering of genes regulating hematopoiesis and for their involvement in the deletion of the long arm of chromosome 5 in myeloid disorders). Proc Natl Acad Sci USA (1987) 84, 2970.

28) Sherr CJ, Rettenmier CW, Sacca R, Ruossel MF, Look AT and Stanley EA : The c-fms protooncogene product is related to the recepter for the monounclear phagocyte growth factor, CSF-1. Cell (1985) 41, 665.

29) Le Beau MM, Albain KS, Larson RA, Vardiman JW, Davis EM, Blough RR, Glomb HM and Rowley JD : Clinical and cytogenetic correlations in 63 patients with therapy-related myelodysplastic syndromes and acute nonlymphocytic leukemia (further evidence for characteristic abnormalities of chromosomes No.5 and 7. J Clin Oncol (1986) 4, 325.

30) Young DC, Griffin JD : Autocrine secretion of GM-CSF in acute myeloblastic leukemia. Blood (1986) 68, 1178-1181.

31) Young DC, Wagner K, Griffin JD : Constitutive expression of the granulocyte-macrophage colonystimulating factor gene in acute myeloblastic leukemia. J Clin Invest (1987) 79, 100-106. 


\title{
Studies on hematopoietic progenitor cells in acute leukemia and
}

\author{
related disease
}

\author{
Part 1. Studies on leukemic blast progenitors in acute \\ nonlymphocytic leukemia \\ Masataka Nishimura \\ Department of Internal Medicine, \\ Okayama University Medical School, \\ Okayama 700, Japan \\ (Director : Prof. I. Kimura)
}

Colonies derived from leukemic blast progenitors were sequentially observed on Days 3, 5, 7, 10 and 14 to evaluate the relation between the kinetics of leukemic blast progenitors and types of acute nonlymphocytic leukemia (ANLL), chemotherapeutic response and leukemic cell kill kinetics. The cells were obtained from 34 patients with typical ANLL and 6 with hypoplastic ANLL. The leukemic colony assay was performed.

Colony-counts (CCs) were somewhat higher in M2 and M5 patients than in patients with other FAB subtypes. CCs were significantly lower in patients with hypoplastic ANLL than in those with typical ANLL (22 \pm 25 vs $148 \pm 205, \mathrm{P}<0.02)$. Time required for $50 \%$ reduction in CCs from maximum CCs (Days for 50\% reduction) was longer in relapsed than in previously untreated ANLL patients $(6.5 \pm 2.3$ days vs $3.3 \pm 1.5$ days, $\mathrm{P}<0.01)$. In patients with remission both of CCs on Day 7 and maximum CCs were higher than in patients without remission (198 \pm 187 vs $69 \pm 77, \mathrm{P}<0.05$ for CCs on Day $7 / 233 \pm 188$ vs $107 \pm 66, \mathrm{P}<0.05$ for maximum $\mathrm{CCs}$ ). Time for $50 \%$ reduction was significantly shorter in patients with remission $(2.4 \pm 0.7$ days vs $4.2 \pm$ 1.2 days, $\mathrm{P}<0.02)$. The correlation between $\lceil$ days for $50 \%$ reduction」 and $\lceil$ acceleration of decrease at Phase II of leukemic cell kill curve $\rfloor$ was noted.

These findings indicate that the sequential observation of colonies derived from leukemic progenitors is useful not only for the prediction of the chemotherapeutic response but also for analysis of pathophysiological aspects of ANLL. 